Studia Anglica Posnaniensia 47/4, 2012

doi: 10.2478/v10121-012-0017-5

\title{
MEMORY AND FORGETTING IN LISA APPIGNANESI'S THE MEMORY MAN
}

\author{
DAGMARA DREWNIAK
}

Adam Mickiewicz University, Poznań

\begin{abstract}
The aim of this paper is to look at Lisa Appignanesi's novel The memory man ([2004] 2005), which won the 2005 Holocaust Literature Award, and examine the patterns of remembering and forgetting as indispensable aspects conducive to the formation of Jewish identity. The main character of the book, Bruno Lind, a Holocaust survivor and a scientist dealing professionally with the complicated neurological issues of remembering and losing memory, tries to recollect his war memories during a journey to the places of his youth which are at the same time the sites of his and his family's trauma. The Holocaust, change of identities, the war memories and finally the stay at the DP camps and escape to Canada return to Bruno Lind's mind in order to be passed onto the next generation and remembered. This article shows Appignanesi's novel as an important contribution to the discussion on the role of memory in Jewish identity.
\end{abstract}

Wanting to forget had been replaced by wanting to remember.

(The memory man, 7).

Lisa Appignanesi's versatile writing includes fiction and non-fiction (volumes of essays on various literary and cultural issues). Appignanesi was born in Łódź in 1946 as Elżbieta Borensztejn to a Jewish family who had survived the Second World War. She spent her early formative years in Łódź and left Poland with her family at the age of three to be brought up in France and Canada. She now lives in England. She has been an active and prolific writer, university lecturer and critic, as well as deputy president of English PEN. Her writing comprises a wide range of texts, including fiction such as Memory and desire (1991) and a novel entitled Paris requiem (2004), non-fiction such as Losing the 
dead: A family memoir (1999) and edited volumes The Rushdie file (1989, coedited with Sara Maitland) and Dismantling truth: Reality in the post-modern world (1989, co-edited with Hilary Lawson). Her texts frequently, though not always, refer to the way memory functions, and offer a discussion of memory and its connections with Jewishness and the Holocaust, which Appignanesi focuses on also in the text selected for this paper. In the novel The memory man ([2004] 2005), which won the 2005 Holocaust Literature Award, she analyses the ways in which memory plays a crucial role in finding one's past, roots and identity. The aim of this paper is to look at this text and examine the patterns of remembering and forgetting as indispensable aspects conducive to the formation of Jewish identity.

In The memory man $^{1}$, the intersection between memory and forgetting mainly concerns a Holocaust survivor, whose repression of memories is a metaphor for his escape from reliving what he experienced. However, Anne Whitehead, in her book titled Memory (2008), concludes her discussion with a proposal of the "art of forgetting", which may serve as an indication of the future direction of memory studies. She writes: "It seems to me that forgetting, considered in all of its complexity, deserves to be taken seriously, both because it is an inseparable and not always sufficiently recognized aspect of memory itself, and because some measure of forgetting is a necessary requirement for personal and civic health" (Whitehead 2008: 156-157). This particular mode of escaping from the torment of memory cannot be fully accepted or explained by scholars such as Paul Ricoeur (2004), whose study on the subject of memory proves that forgetting leads to amnesia, and thus amnesty. This requires forgetting to be seen as an opposition of remembering, and thus in reference to the problem of the collective memory of Holocaust survivors it cannot be taken into consideration. Ricoeur's views, though expressed mainly through philosophy and history can be applied to narrative as well. His doubts about "ars oblivionis" (Ricoeur 2004: 505) echo the quandaries which both fiction and non-fiction pose. $\mathrm{He}$ writes that "the ruses of forgetting are still easy to unmask on the plane where the institutions of forgetting, the paradigm of which is amnesty, provide grist to the abuses of forgetting, counterparts to the abuses of memory" (Ricoeur 2004: 500). Therefore despite a whole range of arguments for a "happy memory," to

Lisa Appignanesi's novel could be viewed in a wider context of the Holocaust writing which ranges from the already classical texts by Elie Wiesel and Primo Levi through Adele Wiseman, Clara Kramer, and Janina Bauman, to name just a few, representing exemplary Canadian, US and English Holocaust voices respectively. The aim of this paper, however, is to treat Appignanesi's novel only as a case study of rendering the story of a Holocaust survivor in the form of fictional narrative. Her text is also interpreted here as a voice from the writer belonging to the second generation of survivors, whose experience of the Holocaust is not restricted by the experience of Auschwitz. 
use Ricoeur's term, it is still essential not to cross the boundaries of abuse of memory, which may stem from forgetting.

Karl Simms (2003: 121) emphasizes Ricoeur's belief "in the duty to remember. Collective remembrance constitutes history. If pardon is a gift, then it is tied to memory in that when something is given, there is a debt on the part of the recipient". Moreover, neither remembering nor forgetting belong to the sphere of conscious decisions, and thus are passed down to subsequent generations. Ellen S. Fine notes that the existence of the post-Holocaust generation makes the question of memory constantly vital. She expands the term "second generation" in a similar way to Eaglestone (2004) by saying that it "is used to characterize the generation born after the war, generally referring to children of survivors. However, my [Fine's] use of the expression is more comprehensive, encompassing those born during and after the war, including those who did not directly participate in the Holocaust but who have come to endure the psychic imprint of the trauma" (Fine 1998: 186).

In the context of collective memory and its influence on the next generation, Marianne Hirsch's views on postmemory need to be mentioned. In her Family frames. Photography narrative and postmemory, Hirsch defines the notion of diasporic experience of the generation in question and calls for an idea of 'absent memory,' which is typical of those "whose parents never spoke of their abandoned world or of their wartime experiences and who thus had almost no access to the repressed stories that shaped them" ([1997] 2002: 243). ${ }^{2}$ This finds itself at the very centre of postmemory, thus corroborating the inability to forget, even if the survivors undertake the effort of erasing the past and do not inform their children about it. Nonetheless, she claims that "None of us ever knows the world of our parents. We can say that the motor of the fictional imagination is fuelled ... [by] a need ... to re-member, to re-build, to re-incarnate, to replace, and to repair" (Hirsch [1997] 2002: 242-243). This fusion of collective and absent memories is, according to Fine (1998: 187) the main domain of the post-Holocaust narration. The passage from forgetting to remembering, though painful, becomes the main motif of the story in The memory man.

2 Michael F. Bernard-Donals in his Forgetful memory: Representation and remembrance in the wake of the Holocaust contrasts the term "absent memory" with his idea of "forgetful memory" which is seen by him as "the interruption of the fabric of memory by the trace or effect of the event that it can't contain" (2009: 59). His study is mainly concentrated around studying visual representations of trauma. Yet, his views on the oppositions between these two modes of memory are vital in the understanding of Amelia's behavior in The memory man. What Bernard-Donals also adds to his definition of "forgetful memory" is that if "the second generation witness experiences regret at this inaccessibility in absent memory, there's no such regret in forgetful memory" (2009: 59). Such an approach situates Amelia in the very center of "absent memory" though the concept of Bernard-Donals is also an interesting viewpoint to consider. 
From the very first pages of her novel, Appignanesi makes memory the focus of the book. Not only the novel's title but also the mottos she borrows from W.G. Sebald's Austerlitz and Marcel Proust's In Search of Lost Time make these considerations on lost memories and re-claiming the past the leading motifs in her own story. Moreover, her chapter titles "Present Tense", "Past Present", "Past Historic", and "Return" exhibit significant allusions to the main concern of the novel, and suggest intricate connections between the past and the present and the impossibility of dissolving these categories in one's life.

The main character of the book, Bruno Lind, a scientist dealing professionally with complicated neurological issues of remembering and memory loss, tries to recollect his war memories during a journey to the places of his youth, which are at the same time the sites of his and his family's trauma. The Holocaust, change of identities, war experiences and, finally, living in DP camps and escaping to Canada, return to Bruno Lind's mind in order to be passed on to the next generation and preserved. Attending a conference of neuroscientists in Vienna, where Bruno was born, brings him closer to his childhood memories, and his decision to further explore the past and to travel to Poland is the result of the suppressed memories he reluctantly begins to recall.

Denial of trauma is a well-known experience. For Bruno, in his early youth, it becomes a daily practice aided by the new life he is offered by a doctor from a DP camp, whom Bruno helps as an apprentice for two years. In 1948, Bruno receives all of the necessary papers allowing him to enter Canada, which "felt innocent" (The memory man, 65) and begin his education in medical sciences. This total change of place and work allows him to forget and distance himself from his war memories. Arriving in Canada at the climax of autumn, he marvels at the landscape, "ablaze with red and russet leaves [which] ... gave way to gusting winds. Snows followed in their wake, and the city took on a coat of white. He loved the white and the stillness that came with it. ... [It] filled him with a delight he couldn't name. It was a little like the snow. It swallowed everything outside and made it invisible" (The memory man, 65-66). This whiteness and innocence of his first Canadian experiences creates a chance to begin a new life and erase his trauma with the blankness of novelty. Finding refuge in the landscape is also connected with the nature of the personal contacts Bruno is able to establish at the beginning. Although polite, they are superficial and cold, and do not encourage any deeper connection. Bruno thus never has an opportunity to confide in someone about his past. This is why it shocks Bruno to discover in Vienna that after so many years his memories, though denied, are stored in the deepest corners of his mind. His stay in Austria begins with a symbolic welcome at the airport when a person waiting for Bruno holds a cardboard sign that says 'Memory' in order to greet scientists attending the symposium. Then, during his conference speech, he switches into German and "fe[els] the 
familiarity of the speech on his tongue, despite the sudden strain on his lips and cheek as long dormant muscles were prodded into action" (The memory man, 17). Led by some unexplainable instinct, Bruno goes to see his childhood house and accidentally crashes into a young boy skateboarding in the street. Bruno is knocked down and loses consciousness for a while. This triggers a memory of a similar event in the remote past:

\begin{abstract}
Funny how he had altogether forgotten that attack in front of the childhood apartment until this afternoon with its painful near repetition. Forgotten because so many worse events had come in its wake, displacing it in a sequence of horrors. It must have been the physical act of falling which had awoken the young Nazi thugs who leaped at him in 1938. No, no... that wasn't quite right. It was the whole associative sequence, this city, the street, the woman bending towards the window, one thing after another, a whole series of cues activating the neural networks to give him the memory again
\end{abstract}

(The memory man, 13).

The memory of the long-ago attack in the street evokes memories of his father, who frequently suffered from similar attacks. The antisemitic atmosphere of Vienna in the 1930s led to his father's disappearance and probable death. Yet, there is another, strange coincidence of facts when Bruno overhears the name of a scientist from Poland registering for the conference, Aleksander Tarski. Hearing this name provokes intense feelings in Bruno, since it is the name he once stole from a heavily wounded Partisan who had recognised him as a Jew, and which he used as an alias in order to hide his Jewishness and become an active member of the Polish underground resistance during the war. This man seems to be too young to be Bruno's contemporary. Nevertheless, Bruno begins to reconsider his past even more, and realises that "by some perverse instinct, he had followed a name he didn't want to think about, and it had led him to a seam of his past he had lost, but not, it now seemed, forever. It had been kept passionately alive for him by an old woman who contained a young one, almost intact" (The memory man, 251). Due to his connection with Tarski and meeting a journalist from Poland who attends the conference, as well as his daughter Amelia's interest, Bruno agrees to take part in a journey of self-discovery to Cracow and its surrounding areas. The old woman mentioned in the above quotation, the journalist's mother who is suffering from Alzheimer's, turns out to be the woman Bruno fell in love with in his youth when he spent some time hiding in a farmhouse in the countryside.

The familiarity of Vienna on the one hand, and Bruno's alienation in the city, on the other, can be understood in light of his experience of exile. He finds himself on the crossroads, torn among his various concepts of home, none of which he can call a real home. In Canada Bruno finds forgetting and oblivion, but is painfully aware that Canada is not the country of his origins, of his 
grandparents and of his childhood. Vienna at the end of the $20^{\text {th }}$ century is no longer his remembered childhood home, but merely the site of the painful memory of his father's disappearance. And Poland, to which Bruno travels after the conference, turns out to stir the worst memories of his mother's and sister's murders, death of his grandparents, and his own brush with death. Canada's sterility, and Austria and Poland being virtually graveyards for Bruno, create an intense feeling of unbelonging, typical of people living in exile who have survived the Holocaust. Marianne Hirsch claims that such emotions are characteristic not only of those who have suffered war trauma, but even of their children: "'Home' is always elsewhere, even for those who return to the Vienna, the Berlin, the Paris, or the Cracow their families had to leave, because the cities to which they can return are no longer the cities in which their parents lived as Jews before the genocide, but the cities where the genocide happened and from which they and their memory have been expelled" (Hirsch [1997] 2002: 243). This exiled condition, together with his career as a skilled neuroscientist, forms his identity.

Bruno professionally explores the ways in which memory functions, and this leads him to various thoughts concerning his own fate. Being an expert, Bruno comes to the conclusion that "our understanding of memory, which must be the foundation of mind, is still in its infancy" (The memory man, 18), despite the development of neuroscience. As a scientist he strives to discover a cure for memory loss, while, in his private life, he wishes to forget the past. Aware of the numerous ways of finding oblivion, Bruno is confronted with doubts: "Why was it that, although our brain cells are always changing, we remember even when we want to forget? But the world had been transformed since then. Wanting to forget had been replaced by wanting to remember" (The memory man, 7). Central to the whole story, this thought is a recurrent motif in the next generations' quest for identity as well as the more general concept of collective memory. His denial of remembering and a bold certainty that it is possible to suppress memories are juxtaposed with his visit to the places which were once familiar. Bruno realizes very quickly that "the fear was still alive, despite the passage of years" (The memory man, 4). Shocked as Bruno is, he discovers:

a memory solidified by repetition, so that it became a part of him, was felt - a collective memory which was also individual, his own. Here. Recorded in these walls. Flashbulb memories. That's what they called them in the profession. Shocking, traumatic experiences or images, reproduced by the media time and again, and bringing with them great floods of adrenalin and steroids, picked up by amygdala and the hippocampus, imprinted. Here, inside. In his brain

(The memory man, 39). 
He is able to explain the processes governing such memories in the brain, but is reluctant to acknowledge that it is happening to him, that these are his own suppressed memories of the war trauma that are ready to surface in his own brain. Bruno goes even further in his negation, as if he cannot believe the recollection might happen to himself. When he is immersed in a professional discussion with a few fellow scientists, he convinces them "If the memory's become longterm, it'll come back with the appropriate triggers" (The memory man, 51). He is still unaware, however, that such triggers have already appeared around him: the language and the landscapes of his childhood. At the beginning he tries to look at himself with the distance of a professional scientist who constantly speculates on the way memory functions. As a specialist, he cannot accept the fact that he does not remember things he wants to remember, and vice versa. Although Bruno remembers the moment his father drew a nerve cell for him he does not remember whether he missed him after his father's disappearance. Bruno even asks an expert question:

Did the brain distinguish between registering real death from real-time death, as
death on television was oddly called? The answer probably lay in the level of fear
- recurring fear [as] he may not have witnessed Hitler's rallying cry to the Austri-
ans then, but somehow it had etched itself with pictorial realism on his mind, so
that he could see huge massed crowds ... Like New Yorkers, who vividly remem-
bered the destruction of the Twin Towers as a real event, whereas in fact they had
only witnessed it virtually

(The memory man, 10).

Bruno's decision to forget is not understood by his adopted daughter, Amelia, who is another triggering force. For many years she accepted her father's silence about his past but, despite her Afro-American origins, she is compelled towards the Jewish faith and becomes an active member of a synagogue. During their journey to Poland, when Bruno refuses to take Amelia to Auschwitz, she exclaims:

What else fathers are for ... is introducing their children to the history that made them ... because the history that made them gets passed down, willy-nilly ... Even if you don't talk about it, it's there. It's there in your silences, in your gestures, in the odd things that make you angry, like filling in forms. In your sudden starts. In the way that you used to hug me as if I might disappear down an Alice hole at any minute

(The memory man, 124).

This appeal to retell Bruno's stories, which comes from Amelia, may also be seen in the context of Paul Ricoeur's "narrative remembrance," a notion, which is supposed to denote the way memories are stored, and, through a reconsideration of such memories in the narrative, a tribute is paid to the victims of the 
Holocaust and such a writing comprises a warning to the generations to come. According to Kearney: "Narrative remembrance, as analysed by Ricouer, can serve two functions: it can help us to represent the past as it really was, or to reinvent it as it might have been" (Kearney 2004: 108, italics in the original). In life writing and historical writing the primacy would granted to the former mode, whereas in fiction to the latter, as Kearney claims, but in both cases the importance to remember the Holocaust and to retell, or "reinvent" it, is an important duty of the survivors and their children.

Amelia's feelings as well as her conversion follow the paths of postmemory described by Hirsch, who claims that "the children of exiled survivors, although they have not themselves lived through the trauma of banishment and forcible separation from home and the destruction of that home, remain marked by their parents' experiences" (Hirsch [1997] 2002: 243) as well as Ricouer's "narrative remembrance". This motif of knowledge and feeling shared by the second generation is known to Appignanesi herself, who in her memoir Losing the dead confronts her emotions about her parents' past, claiming, "Memory, like history, is uncontrollable. It manifests itself in unruly ways. It cascades through the generations in a series of misplaced fears, mysterious wounds, odd habits. The child inhabits the texture of these fears and habits, without knowing they are memory" (1999: 8). Eaglestone, in his The Holocaust and the postmodern (2004), extends the concept of postmemory to "all of us who come after the Holocaust, and who reflect on it" (2008: 73). He ponders over such questions as "how does the 'post-Holocaust memory' of those who did not live through the events relate to that which it cannot take on board fully?" (Eaglestone 2008: 73) and discusses the degree to which postmemory affects people through storytelling, as "these narratives [post-Holocaust narratives], told to us as well as told by us, acted out by us and acted out in relation to us, are still interwoven and equiprimordial. We are interpellated, identified by and in a range of different memory narratives" (Eaglestone 2008: 75). This idea of narrating memory, as expressed by Eaglestone and close to Appignanesi as well coincides with Ricouer's conviction that remembering in the context of the Holocaust is, first of all, a moral duty of the human race inasmuch as retelling true stories of death and survival saves them from banality (Kearney 2004: 107).

This moral dictate together with the concept pf postmemory refer to Amelia, irrespective of her cultural origin, as she is "interpellated" and defined through her father's experiences and his silence. Irena, the Polish journalist, also shares such a view and observes that "the survivors are growing so old, they'll be gone soon, so we want to know before it's too late" (The memory man, 87). Amelia is infected with a certain amount of her father's trauma, but she is also an extremely vital person, and attempts to cure her father of his fears and misery and thus legitimise her Jewishness and her need to remember. Amelia may seem to 
be in a 'more comfortable' position, able to be indifferent towards her father's past, since she is merely adopted by Bruno and his wife, not related by blood. Nonetheless, she desires to know about Bruno's difficult past and proves herself to be strong enough to face it, since her strength and vigour give her the ability to witness trauma.

Moreover, her childhood, as she claims, was tinged with her experiences of prejudice as an Afro-American. The journey that she encourages her father to undertake is a quest for memory through the places Bruno lived in during the war, places where he hid with his mother and sister and where they were killed. Amelia would like to push her father to the extreme and accuses him of not wanting to visit Auschwitz. This is too much for Bruno. In an outburst of agitation, he yells at her that he is afraid of not having proper feelings there, or perhaps not even feeling anything. Instead, he offers to go to the New Jewish Cemetery where members of his family are buried, and this particular moment triggers another feeling of readiness to see the countryside where his mother and sister were killed. He experiences this disposition in a very specific way, as if "the dead were murmuring to him, talking" (The memory man, 130). Reliving the trauma is a difficult experience for Bruno, but Amelia finds a way to acknowledge these deaths and negotiates with a local woman the possibility of placing a modest stone with an inscription commemorating Bruno's family, those who are "remembered by Bruno Lind and his daughter, Amelia" (The memory man, 189). This moment of emotional terror is like a rite of passage for Bruno, similar to a permit to live and die in peace. But it is also what he was most afraid of: re-collection of the terrifying memories. His account underscores the tragedy as well as his regained, acute memory: "My mother and sister were shot here. In front of my eyes. They're buried near that tree where the little girl is swinging. My sister played there too. She was barely six-years-old. I promised I'd come back" (The memory man, 188). Such closure and mourning seem to be important elements of one's identity (Eaglestone 2008: 96). The processes of denial and surfacing through blurred memory are both widely discussed in critical texts and Appignanesi's novel. In the denouement of the book, the importance of memory in the formation of a child's identity is presented: "It was all so strange. The way memory was so crucial to who one was, the very foundation on which identity was built" (The memory man, 231). Although Bruno's final recollection triumphs over the recurrent fears, Amelia now has to face this past.

Bruno's desire to forget seems to constitute a natural part of a Holocaust survivor's identity. Bruno's repression of war memories is also shaped by his experiences at the DP camp he lived in. There was painful irony in this situation, firstly because the location of the camp in Germany meant he had to willingly apply to get there: "The camp itself was in Germany. Where else could 
these endless ironies of the supposed post-war take him but through Austria into Germany? The enemy - hated, feared, plotted against, fought, outsmarted too late. He had a feeling that German soil would belatedly swallow him up never to regurgitate him" (The memory man, 60). And, secondly, since he only possessed his Polish documents he had to convince camp officials of his Jewishness. This is an extremely difficult situation for Bruno, as it would be for any Jew, since "he had hidden who he was for so long, had masqueraded as an Aryan for so many years, there seemed to be no going back. Lies grown into truths. The Nazi logic of race had taken them all" (The memory man, 59). Having received a pass to enter Germany and become a displaced person, Bruno meets other people similar to him in the DP camp. Never having spoken Yiddish, only German, he now has to learn another language in order to fit in with the group. This sequence of events from Bruno's life show how much he has to forget in pristine Canada in order to lead a smooth life, devoid of any emotional turbulence. Through these factors and meeting Irena's mother, Bruno's lover and saviour, his journey in time uncovers a totally forgotten past. Bruno, a memory specialist, is astonished by what he is able to recall: "No. Science wouldn't, couldn't give him explanations that dealt adequately with the complexity of the experience of these past weeks. He felt at ease with that knowledge now. Felt strangely light too, in the midst of sadness, as if he would have liked to immerse himself even more deeply in that recollected world, rather than bear its burdens by avoiding it" (The memory man, 247). Irena's mother's flashbacks of memory, which are a frequent occurrence in patients with Alzheimer's, "triggered a supposed recognition and launched a waterfall of speaking memory" (The memory man, 249). This feat of memory coincides with a probable lack of recognition, since she is now an old, ill woman and Bruno an old man. The greatest paradox is that Bruno, a healthy person, managed to forget, whereas Irena's mother still remembers, despite the fact that she was said to have lost a great part of her memory:

he had forgotten and she had remembered. Had even remembered the name he
had worn and which had belonged to a man he thought dead, a man he had felt
had tried to kill him ... Aleksander Tarski. His personal memory had functioned
in the spirit of what collective memory had made of the time - Poles and Jews
mired in hatreds, when the killing machine which made murderers and victims of
them all had in the first instance been put in place by a Nazi regime that despised
them both. That was history ... and [she], whom the neurologists would have sup-
posed to have lost her name memory almost first of all, had remembered through
the tangles of her own forgetting

(The memory man, 248).

As painful as they are, Bruno's recollections liberate him from his fear of returning to the past. Overcoming this fear allows him a more peaceful return to 
Canada. When Bruno faces his loss, it coincides with the discovery of his daughter's identity and inner soul. Amelia, whose desire to discover the past results in finding a half-sister, much older than her, finds satisfaction in pushing her father to be able to commemorate the dead and in reclaiming memories from her father's past.

Lisa Appignanesi's novel, as well as her non-fictional Losing the dead: A family memoir (1999), apart from presenting narratives concerning a particular character (Bruno in The memory man and Appignanesi's parents in Losing the dead), also offer philosophical disputes on Jewishness and the place of memory, alluding to Pierre Nora's Les lieux de mémoire (1989). Her considerations refer to the role of Jewishness in contemporary Europe when her characters visit the old Jewish district of Kazimierz in Cracow, where there are almost no Jews but Jewishness flourishes in a very acutely performative way. She calls it "the heritage industry" and describes it as "tableaux, living snapshots of the supposed past culled from an intricate continuum and re-presented as attractions. An unruly sea trimmed into a garden pond with a couple of goldfish for effect. This was the memory of business at work ... And since there were no Jews here, memory with all its distortions was all you got. It was easier, after all, to love the extinct" (The memory man, 122). Such a spectacle always brings pain and guilt of being the survivor. Another set of feelings which arises is the embarrassment of witnessing the frequently kitsch presentation of Jewishness to fit into the atmosphere in order to satisfy a whole range of tourists. In such situations, according to Appignanesi:

[the] hoary wartime truism leaped into ... [one's] mind. Poles and Jews recog-
nized each other. Germans were less dangerous. They couldn't detect the subtle
differences. ... This Pole was masquerading as a Jew out of folklore, a stetl Jew
wearing fancy dress. It was like watching a minstrel show where the whites black-
ened their faces to perform a pastiche of black life. Watching it in a slave grave-
yard
(The memory man, 121).

Bruno's experience during the trip to central and eastern Europe, through the mixture of emotions and revelations it offers, provokes a reconsideration of his identity through a re-collection of his memories and facilitating his daughter's postmemory. His "condition of exile from the space of identity, this diasporic experience" (Hirsch [1997] 2002: 243) undergoes some changes, and he emerges a different person. Yet, Bruno acknowledges that it is impossible to fully erase memories from one's life. Though suppression of war memories is available temporarily, Appignanesi's novel seems to prove Ricoeur's (2004: 505) statement referring to the unattainability of "ars oblivionis" and thus postponing Whitehead's (2008: 156-157) proposal of "the art of forgetting" at least for the 
generation of Holocaust survivors and their children. Bruno concludes his quest with the feeling that his scientific approach to memory and forgetting has been unable to fully protect him from grief and a series of coincidences which have led him to deeper recognition. Not only does it paradoxically bring him closer to these memories through the conference he attends, but also equips his adopted daughter with the right to know. To a large extent, it is Amelia's 'absent memory,' to use a term Hirsch borrows from Nadine Fresco, which leads Bruno to follow the path of his forgetting towards remembering.

\title{
REFERENCES
}

\section{PRIMARY SOURCES}

\section{Appignanesi, Lisa}

[2004]

2005 The memory man. London: Arcadia Books.

\section{SECONDARY SOURCES}

\author{
Appignanesi, Lisa \\ Losing the dead. Toronto: McArthur \& Company. \\ Bernard-Donals, Michael F. \\ 2009 Forgetful memory: Representation and remembrance in the wake of the Holocaust. \\ Albany, NY: SUNY Press. \\ Eaglestone, Robert \\ 2008 The Holocaust and the postmodern. Oxford: Oxford University Press. \\ Fine, Ellen S. \\ 1998 "Transmission of memory: The Post-Holocaust generation in the diaspora", in: \\ Efraim Sicher (ed.), 185-200. \\ Hirsch, Marianne \\ [1997] \\ 2002 Family frames. Photography narrative and postmemory. Cambridge - London: Har- \\ vard University Press. \\ Kearney, Richard \\ 2004 On Paul Ricoeur: the owl of Minerva. Transcending boundaries in philosophy and \\ theology. Farnham - London: Ashgate Publishing Ltd. \\ Nora, Pierre \\ 1989 "Between Memory and History: Les lieux de mémoire", Representations 26: 7-24. \\ Ricoeur, Paul \\ 2004 Memory, history, forgetting. (Translated by Kathleen Blamey and David Pellauer.) \\ Chicago - London: University of Chicago Press. \\ Sicher, Efraim (ed.) \\ 1998 Breaking crystal. Writing and memory after Auschwitz. Urbana - Chicago: University \\ of Illinois Press.
}


Simms, Karl

2003 Paul Ricoeur. London - New York: Routledge.

Whitehead, Anne

2008 Memory. Oxon - New York: Routledge. 